Ethiopian Journal of Environmental Studies \& Management 7(2): 188 - 196, 2014.

ISSN:1998-0507

doi: http://dx.doi.org/10.4314/ejesm.v7i2.10

Submitted: December 4, 2013

Accepted: March 8, 2014

\title{
SOIL AGGREGATE STABILITY AND ERODIBILITY IN DIFFERENT GULLY SITES IN PARTS OF KADUNA STATE, NIGERIA
}

OLUYORI R.N. AND *MGBANYI, L.L.O.

Department of Geography and Environmental Management, University of Abuja

Federal Capital Territory, Nigeria

\begin{abstract}
This paper assesses soil aggregate stability and erodibility in different gully sites in parts of Zaria, Kaduna State, Nigeria with the aim to provide quantitative information on the variation of some soil properties and their interaction with eroding agents and how this affects soil erosion on the sites. The gullies selected are found at the headwaters of river Saye, Yashi, Guga and Kubanni basins with leached ferruginous tropical soils developed from the basement complex and quaternary deposits drained by River Galma whose pattern is basically dentritic. Soil samples collected from the headscarps, sidewalls and floor of each gully length at $5-10 \mathrm{~cm}$ depth were analysed using standard laboratory methods. Particle size distribution data was used to compute clay ratio index. The result shows that based on aggregate stability the most susceptible to water erosion is the Yashi gully site. Soil particle size distribution in all the gully sites show soil textural classes of silt loam, sandy loam, sandy loam and sandy clay loam at Guga, Saye, Kubanni and Yashi gully sites respectively. Based on clay ratio index (3.58) Yashi show more resistant to erosion followed by Saye with a mean clay ratio index of 4.02, then Kubanni with a mean clay ratio of 10.89 and lastly Guga with a mean clay ratio of 13.06. Results show there is a significant variation of clay, silt, sand, clay ratio and aggregate stability with gully sites at 0.05 levels of significance. A linear multiple regression analysis was used to check the contribution or influence of each independent variable on the dependent variable. Clay ratio index was also derived. The Research concludes that though all sites exhibit gully erosion the reaction of soil properties to environmental conditions varies. Slightly different efforts will be required to turn around the gullies.
\end{abstract}

Key words: Aggregate, Erodibility, Gully, Soil, Stability, Texture

\section{Introduction}

The management and control of soil erosion problem worldwide requires sound knowledge of the interaction of erosion agents (i.e. rainwater and wind) with soil properties (Mallo, 1987; Ojiah, 1998; Ojo, 2000). Anthropogenic activities are often blind to the effects that may result due to disturbance of soil (Clarke and Rendell, 2004; Mallo and Ochai, 2009) There are reports on the menace of gully erosion in several parts of Nigeria, particularly in savanna tropical zone lying on a broad east-west belt, from the eastern highlands to the edge of the Sokoto basin (Ologe, 1986; Juo, and Lal, 1977; Jaiyeoba 1995). The understanding of the nature and properties of soils in any environment is expected to reveal the causes of the soil erosion problem evident in rills, sheet and gully form. Soil properties tend to determine the vulnerability of the soil aggregates and particles to detachment, disintegrate, entrainment and their subsequent transportation (Keli, et al; 2002). For instance soil aggregate stability affects the soil

*Corresponding Author: Mgbanyi, L.L.O

Email: libertwise@yahoo.com erodibility, thus, measurements of soils aggregate stability quantify indirectly the soil erodibility. Measurements of soil aggregate stability avoid the direct influence of other factors such as stoniness, litter and vegetation on soil erodibility during the measurements. Moreover, soil aggregate stability is a synthetic parameter of the soil ecosystem conditions due to its interactions with the flora, fauna, parent material and climate (Imeson, 1984). The role of climate and land use on gully development has been examined in previous studies (Smith, 1982, Stockings and Elwell, 1976) where soil characteristics were considered in the general term of erodibility. Although quite a lot has been done on gully within the Zaria environ (Sheyin, 1989, Ojiah 1998, Ojo 2000 very little quantitative information exist on the analysis of variance of the some soil properties with gully sites as the nature of the regolith material (soil) (Ebisimeju, 1979) will determine the extent of any gully site. This implies that reclamation or other management measures will be peculiar to each site given variation in soil properties and 
their interaction with eroding agents. This study therefore examines soil aggregate stability and erodibility in different gully sites in parts of Kaduna State, Nigeria.

\section{Study Area}

Zaria lies on the undulating plain adjoining the southern scarp of the Jos plateau and is part of the high plains of northern Nigeria. It located within latitude $11^{\circ} 03^{\prime} \mathrm{N}$ and $11^{\circ} 06^{\prime} \mathrm{N}$, and longitude $7^{0} 36^{\prime} \mathrm{E}$ and $7^{\circ} 40^{\prime} \mathrm{E}$. It is about $640 \mathrm{~km}$ from the coast in the NNE section of Kaduna state. The gullies selected are found at the headwaters of river Saye, Yashi, Guga and Kubanni basins (Figures 1 and 2).
Zaria has a dry sub humid tropical continental climate with mean annual rainfall of about $1100 \mathrm{~mm}$ received between April and October (Kowal and Knabe, 1972). River Galma is the major drainage system which is essentially dentritic in nature. The soils are described as leached ferruginous tropical soils (Kowal and Omolokun, 1971) developed from the basement complex and quaternary deposits (figure 2). The vegetation is typically of wood land type and deciduous in character which are surrounded by grasses and shrubs occurring in tussocks.

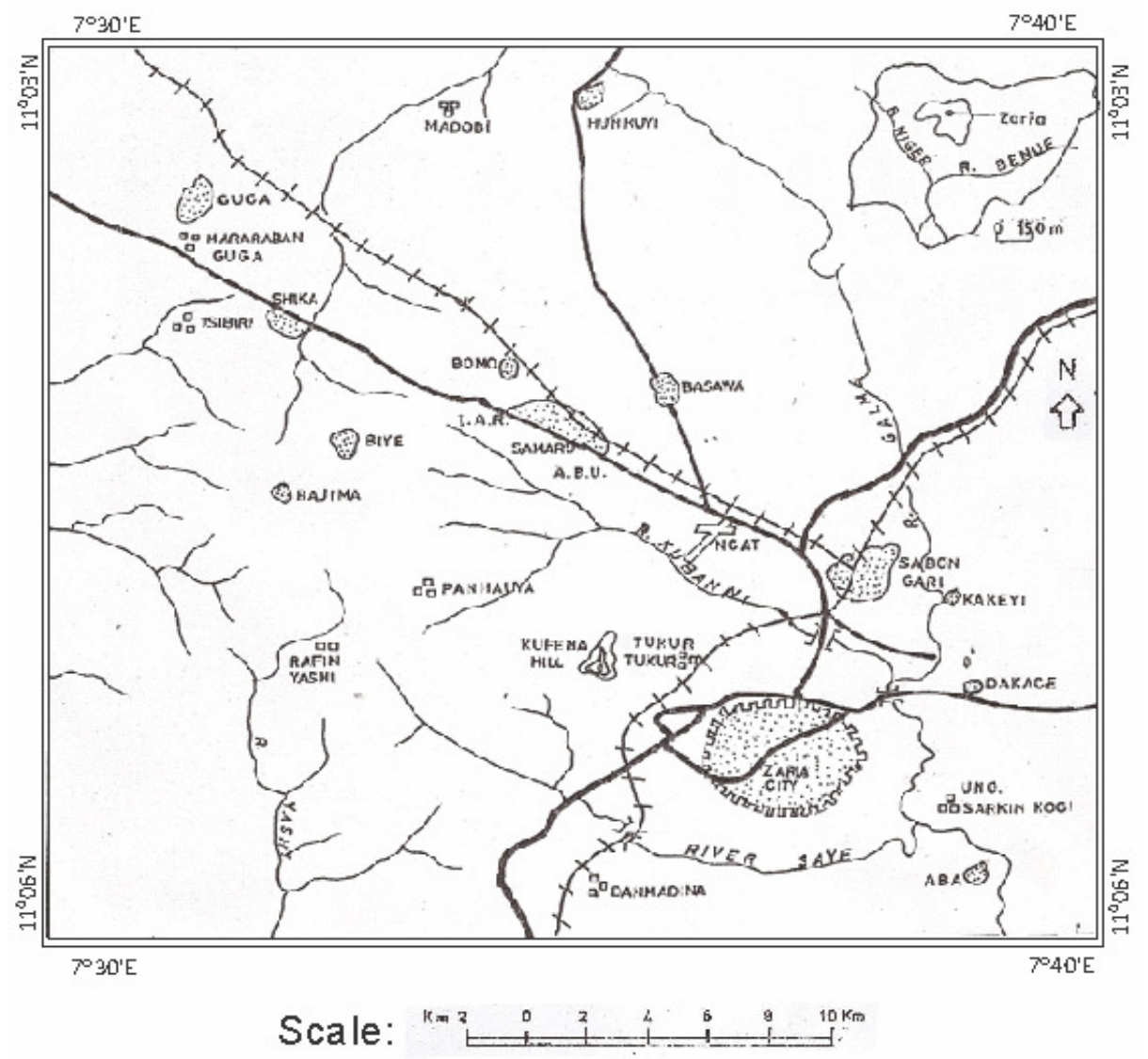

\section{Legend}

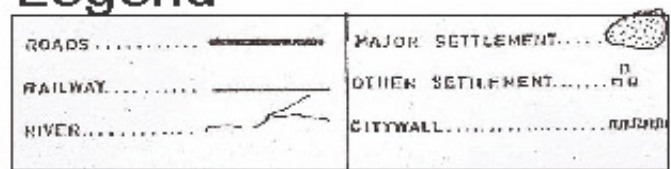

Source: adopted from Zaria sheet 102 S.W

Figure 1: Zaria and its environs 


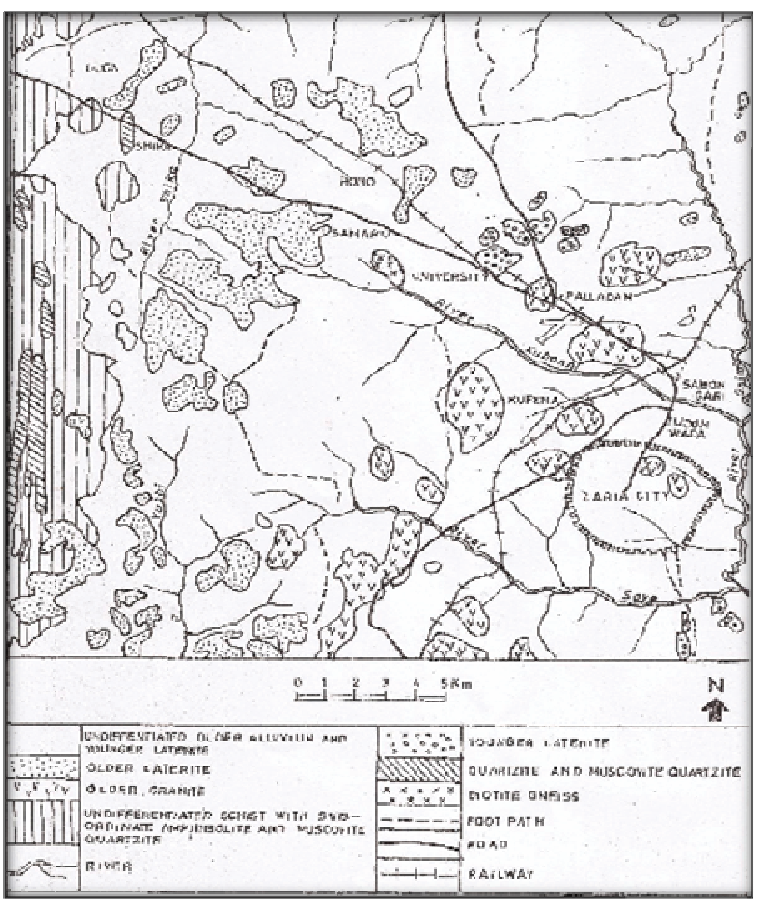

Source: Wright and Mc Curry 1970

\section{Methodology}

Soil samples were collected from the headscarps, sidewalls and floor at 30\%, 60\%, and $90 \%$ of each gully length at $5-10 \mathrm{~cm}$ depth using the hoe and hand spade. Soil samples were air dried and standard laboratory methods were used to determine soil properties (Food and Agricultural Organisation, 1970): soil particle size distribution was determined by hydrometer method and soil aggregate stability was determine by counting the number of droplets (The CND Method).

Aggregates of 4-4.8 $\mathrm{mm}$ diameter were selected by dry sieving. Water-drop test, a burette nozzle with silicon tubing was used, together with a supply system with a constant head. The drops produced with distilled water had a weight of $0.1 \mathrm{~g}$. The water-drops were allowed to fall through a polythene pipe $(15 \mathrm{~cm}$ diameter) from $1 \mathrm{~m}$ height onto aggregates placed on a $2.8 \mathrm{~mm}$ gauge metal sieve. The time interval between drops was $1 \mathrm{~s}$, and it was controlled in order to avoid differences between samples due to the influence of time of wetting on aggregate breakdown. The number of drops required to disrupt the aggregate were counted (Imeson and Vis, 1984; Cerda, 1998).)

Clay ratio index was also computed (Bouyoucos, 1935). Decrease of clay ratio in soils reflects the increase of resistance to erosion. The result of particle size distribution was used to compute Clay ratio to see which gully site shows more resistance to erosion. The Clay ratio index was computed as:

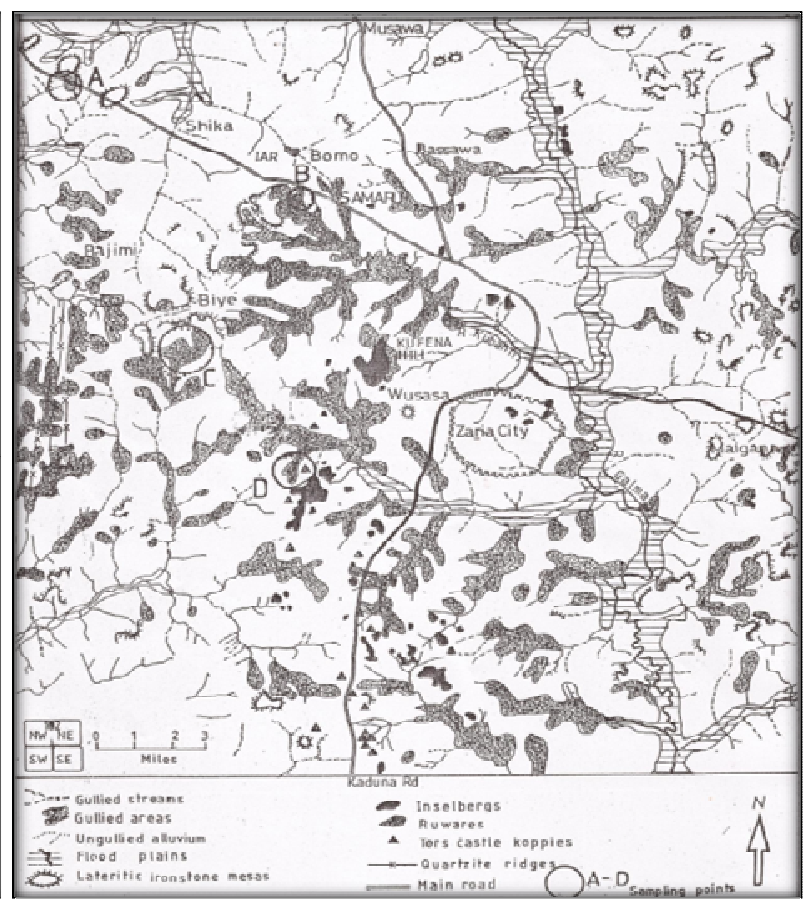

Source: Mortimore, 1970

$$
\text { Clay Ratio }=\frac{(\% \text { Sand }+\% \text { Silt })}{(\% \text { Clay })}
$$

\section{Results and Discussion \\ Soil Aggregate Stability and Soil Particle Size Distribution}

The results of soil particle size distribution as determined by hydrometer method and soil aggregate stability as determine by counting the number of droplets (The CND Method) respectively is as shown in the tables $1 \& 2$ below

Table 1: soil Aggregate Stability (drops)

\begin{tabular}{lllll}
\hline & \multicolumn{4}{c}{ Soil Aggregate Stability (drops) } \\
\cline { 2 - 5 } Slope position & GUGA & SAYE & KUBANNI & YASHI \\
\hline Top & 5 & 5 & 6 & 3 \\
Mid & 5 & 5 & 5 & 3 \\
Base & 5 & 6 & 6 & 3 \\
Mean & 5 & 5.3 & 5.3 & 3 \\
\hline
\end{tabular}

\section{Soil Aggregate Stability}

The higher the mean number of drops taken to break an aggregate of a soil, the more stable is such an aggregate and thus the more resistance is such soil to water erosion than its counterpart which takes less number of drops to disaggregate and thus more vulnerable or susceptible to erosion (Abrishamkesh et al., 2011; Alekseeva et al., 2009; and Amezketa 1999; Portugal et al., 2010). Aggregate stability in an ultisol under different uses, compared with forest. Gully sites at Saye and Kubanni have the highest mean number of drops of 5.3 and 5.3 drops of water respectively for it to 
break. For soil aggregates at Guga and Yashi gully site, it took about 5 drops and 3 drops of water respectively for it to break.

Yashi gully site was more susceptible to water erosion. This explains why the Yashi gully is the largest in the region. The explanations is that the high clay fraction in Yashi should not have made it the largest in depth, length and area coverage, except for its clay That is a dispersible type which is probably under the influences of the moderate silt fraction it contained and this is reflected in its lowest aggregate stability.

\section{Soil Particle Size Distribution}

In Guga the percentages clay, silt and sand on different vertical cross section positions of Top, Mid, and Basal positions was recorded. The top position has $8 \%, 47 \%$ and $45 \%$ of clay, silt and sand respectively. Base position has $8 \%, 55 \%$ and $37 \%$ of clay, silt and sand respectively. Mid position has 5\%,57\% and $38 \%$ of clay, silt and sand respectively. The mean percentage clay, silt and sand in the site are $7.1 \%, 52.7 \%$ and $40 \%$ respectively. The textural class of the soil is Silt Loam.

In SAYE, the percentages clay, silt and sand on different vertical cross section positions of Top, Mid, and Basal slope was recorded. The Top position has $19 \%, 24 \%$, and $57 \%$ of clay, silt and sand respectively with textural class Sandy Loam. The Mid position has 12\%, 26\%, and $62 \%$ of clay, silt and sand respectively with Sandy Loam as textural class. The Base position has $29 \%, 20 \%$, and $51 \% \%$ of clay, silt and sand respectively with Sandy Clay Loam as textural class.

Table 2: Mean soil Particle Size Distribution of the Gullies

\begin{tabular}{lllllll}
\hline GUGA & & \% Clay & \% Silt & \% Sand & CLAY RATIO & Textural Class \\
\cline { 3 - 7 } & Top & 8 & 47 & 45 & 11.50 & Silt Loam \\
& Mid & 5 & 57 & 38 & 19.00 & Silt Loam \\
& Base & 8 & 55 & 37 & 11.50 & Silt Loam \\
\cline { 2 - 7 } SAYE & Mean & 7.1 & 52.7 & 40 & 13.06 & Silt Loam \\
\cline { 2 - 6 } & Top & 19 & 24 & 57 & 4.26 & Sandy Loam \\
& Mid & 12 & 26 & 62 & 7.33 & Sandy Loam \\
& Base & 29 & 20 & 51 & 2.45 & Sandy Clay Loam \\
\cline { 2 - 7 } KUBANNI & Mean & 19.9 & 23.2 & 56.8 & 4.02 & Sandy Loam \\
\cline { 2 - 7 } & Top & 9 & 30 & 61 & 10.11 & Sandy Loam \\
& Mid & 11 & 30 & 59 & 8.09 & Sandy Loam \\
& Base & 6 & 38 & 56 & 15.67 & Sandy Loam \\
\cline { 2 - 6 } YASHI & Mean & 8.4 & 32.7 & 58.8 & 10.89 & Sandy Loam \\
\cline { 2 - 6 } & Top & 27 & 20 & 53 & 2.70 & Sandy Clay Loam \\
& Mid & 21 & 22 & 57 & 3.76 & Sandy Clay Loam \\
& Base & 18 & 20 & 62 & 4.56 & Sandy Clay Loam \\
& Mean & 21.8 & 20.3 & 57.7 & 3.58 & Sandy Clay Loam \\
\hline
\end{tabular}

The Mean percentage clay, silt and sand for the Saye site is $19.9 \%, 23.2 \%$ and $56.8 \%$ respectively, with Sandy Loam as the textural class. In the Kubanni gully site the Top soil section has $9 \%, 30 \%$, and $61 \%$ of clay, silt and sand respectively with Sandy Loam as the texture. Mid $11 \%, 30 \%, 59 \%$ of clay silt and sand respectively with Sandy Loam as the texture. And the Base has $6 \%, 38 \%$, and $56 \%$ of clay, silt and sand respectively with Sandy Loam as the texture. The Mean percentages of clay, silt and sand are $8.4 \%$, $32.7 \%$ and $58.8 \%$ respectively with Sandy Loam as the textural grade.

At YASHI gully site the Top section of the soil $27 \%, 20 \%$, and $53 \%$ of clay, silt and sand respectively with Sandy Clay Loam. The Midsection has $21 \%, 22 \%, 57 \%$ of clay, silt and sand respectively Sandy Clay Loam. The Base section has $18 \%, 20 \%$, and $62 \%$, of clay, silt and sand respectively with sandy clay loam as the textural grade. The mean percentage of clay, silt and sand are 21.8\%, 20.3\% and 57.7\% respectively with sandy clay loam as the textural grade.

Sand content is higher in the Kubanni gully than in the Guga gullies which were nearly all silty loam. Kubanni and Yashi gullies showed similarities in high sand fractions with sandy loam in Kubanni and sandy clay in Yashi Gullies. Guga and Saye also showed similarities in the percentage of silt fractions. Silt fractions were dominant hence, the silt loam classification except at their head scraps which were sandy loam. Guga and Saye gullies have similarity clay in contents. The soils particle size distribution is dominated by sand in the gully site. Earlier reports by scholars show the dominance of sand fraction in the soils of the Nigerian savannah (Kowal and Kassam, 1976; 
Juo and Lal, 1977; Leow and Smith, 1981; Sheyin, 1989; Jaiyeoba, 1995; Yakubu, 2004).

Yashi Gullies have high per cent of sand fraction making aggregation difficult with a less aggregate stability that further makes the soils highly susceptible to erosion. This accounts for the great depth of those gullies. The high silt fraction in Guga accounts for its erosion with shallow channel depth. The depth is restricted by the presence of kaolinitic clay materials which tend to conglomerate with the silt and when exposed to sun light, it hardens and forms an impervious layer that prevents the vertical downward movement of water.

The mean aggregate stability showed that gully Yashi's soil is highly erodible and least cohesive despite the high mean clay content at all the three tested with other gullies. In the Kubanni gully with its light average silt and sand fractions, it is also highly erodible. It is the second largest gully within the Zaria region following the Yashi gully.

Clay Ratio Index

Table 3: Variance of soil properties with site

\begin{tabular}{|c|c|c|c|c|c|c|}
\hline \multirow{3}{*}{$\%$ CLAY } & & Sum of Squares & $\mathrm{df}$ & Mean Square & $\mathrm{F}$ & Sig. \\
\hline & Between Groups & 3688.10 & 3.00 & 1229.37 & \multirow[t]{3}{*}{19.07} & 0.00 \\
\hline & Within Groups & 5156.57 & 80.00 & 64.46 & & \\
\hline & Total & 8844.67 & 83.00 & & & \\
\hline \multirow[t]{3}{*}{$\%$ SILT } & Between Groups & 13404.99 & 3.00 & 4468.33 & \multirow[t]{3}{*}{42.07} & 0.00 \\
\hline & Within Groups & 8497.71 & 80.00 & 106.22 & & \\
\hline & Total & 21902.70 & 83.00 & & & \\
\hline \multirow[t]{3}{*}{ SAND } & Between Groups & 4878.86 & 3.00 & 1626.29 & \multirow[t]{3}{*}{13.32} & 0.00 \\
\hline & Within Groups & 9770.95 & 80.00 & 122.14 & & \\
\hline & Total & 14649.81 & 83.00 & & & \\
\hline \multirow[t]{3}{*}{ CLAY RATIO } & Between Groups & 3935.40 & 3.00 & 1311.80 & \multirow[t]{3}{*}{22.86} & 0.00 \\
\hline & Within Groups & 4590.10 & 80.00 & 57.38 & & \\
\hline & Total & 8525.49 & 83.00 & & & \\
\hline BULK & Between Groups & 0.14 & 3.00 & 0.05 & \multirow[t]{3}{*}{1.43} & 0.24 \\
\hline \multirow[t]{2}{*}{ DENSITY } & Within Groups & 2.61 & 80.00 & 0.03 & & \\
\hline & Total & 2.75 & 83.00 & & & \\
\hline \multirow{3}{*}{$\begin{array}{l}\text { AGGREGATE } \\
\text { STABILTY }\end{array}$} & Between Groups & 79.85 & 3.00 & 26.62 & \multirow[t]{3}{*}{17.33} & 0.00 \\
\hline & Within Groups & 122.86 & 80.00 & 1.54 & & \\
\hline & Total & 202.70 & 83.00 & & & \\
\hline
\end{tabular}
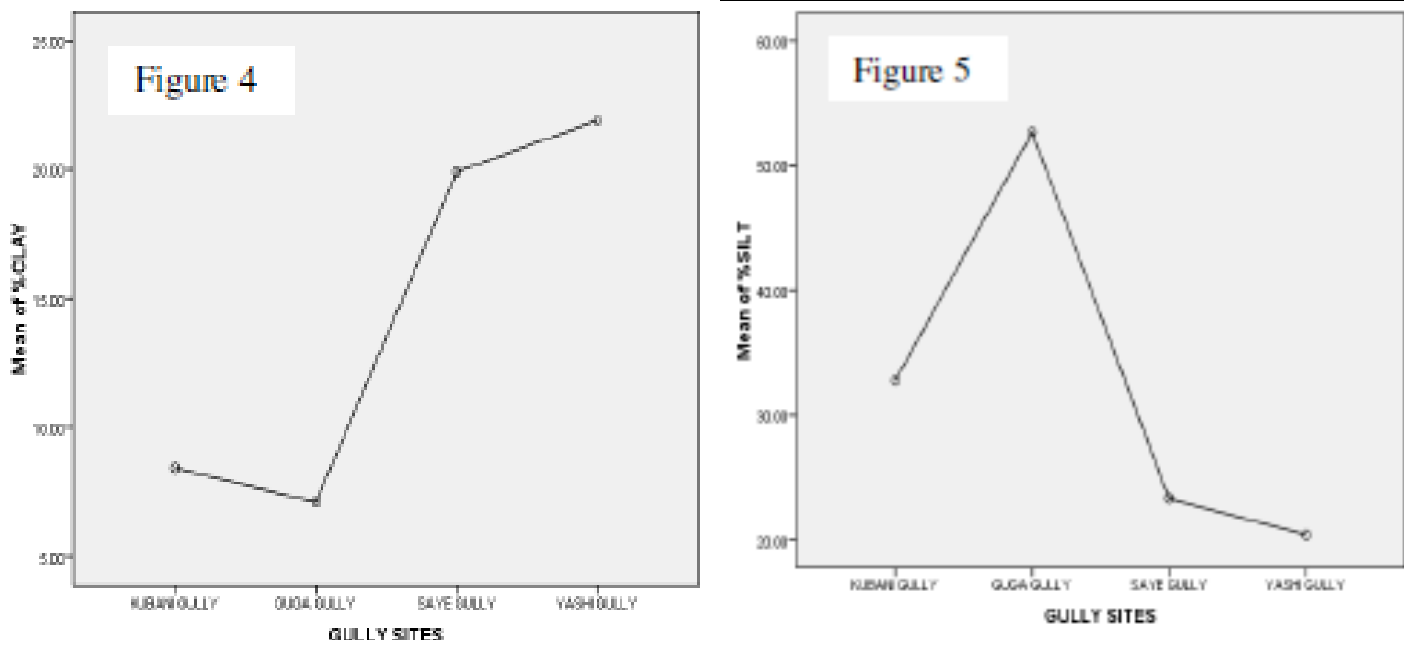

192
Clay ratio index was also derived. Decrease of clay ratio in soils reflects the increase of resistance to erosion (Singh and Khera, 2008). The result show Therefore that YASHI with a Sandy Clay Loam has a mean clay ratio index of 3.58 and is more resistant to erosion followed by SAYE with Sandy Loam textural class which have a mean of 4.02 clay ratio index. GUGA with a Silt Loam soil texture has a Mean clay ratio of 13.06 while KUBANNI with Sandy Loam soil textural class has a Mean clay ratio of 10.89 .

Furtherance to the study, analysis of variance was used to analyse significance variation of soil properties with gully sites at 0.05 levels of significant. The analysis revealed that there is significant variation of clay, silt, sand, clay ratio and aggregate stability with gully sites at 0.05 levels of significance. However, there is no significant variation of Bulk Density with the gully sites at 0.05 levels of significance (Table 3). Means plot for the variations of soil properties with gully sites is also show in figures 4-11 

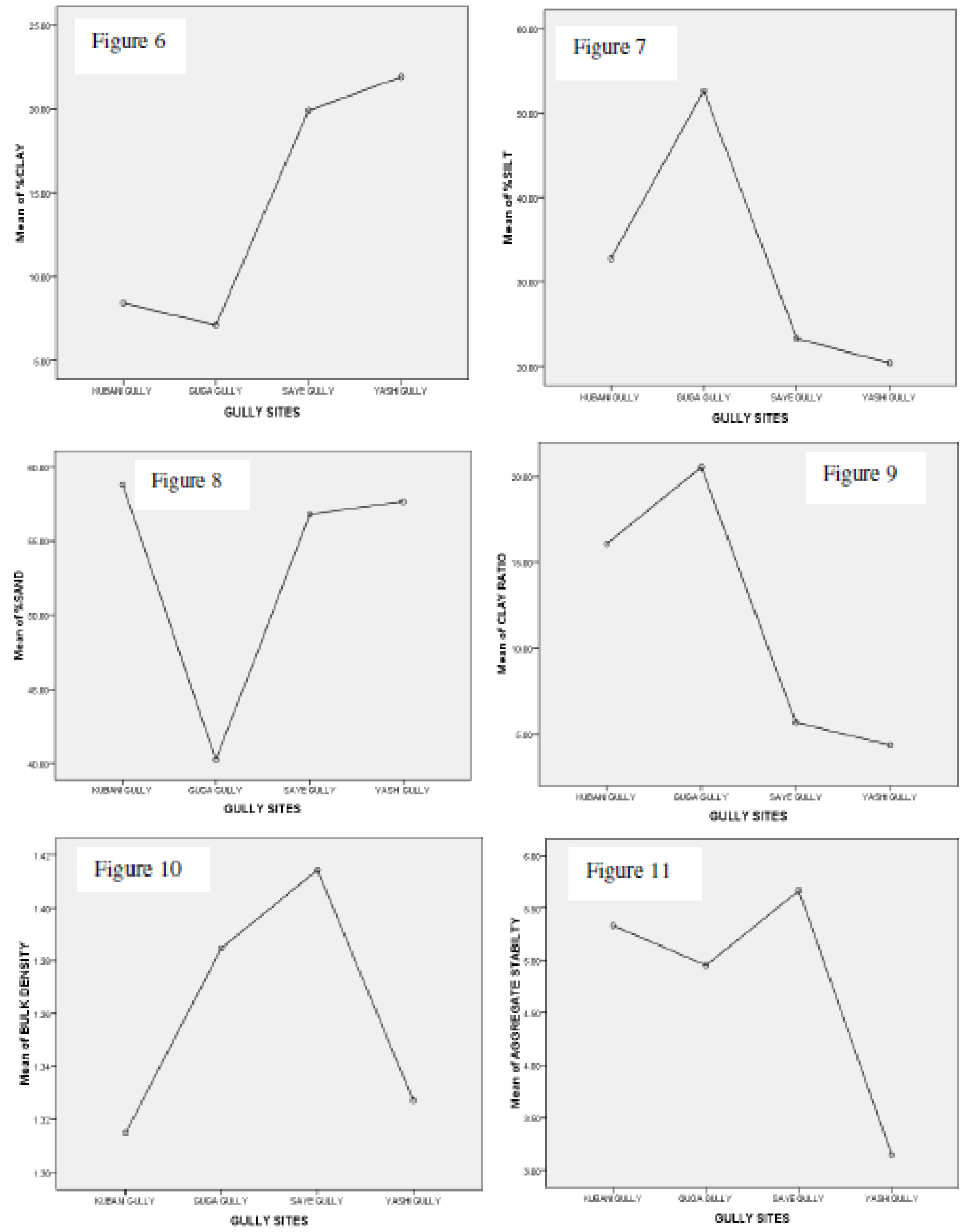

Figures 4-11: means plot for the variations of soil properties with gully sites

Correlation analysis (Table 4) revealed that There is a significant negative relationship between CLAY RATIO and clay (i.e $\mathrm{r}=$ $0.773^{* *}$ ). This implies that the higher the clay, the lower the clay ratio thus the more resistance to erosion. There is also a significant positive relationship between Clay Ratio and \%Silt (i.e $\left.\mathrm{r}=0+.618^{* *}\right)$. This implies that the higher the silt content, the higher the value of clay ratio and thus the less resistance to erosion would be the soil. The same kind of relationship between CLAY RATIO and clay, and between Clay Ratio and \%Silt also exist in

There is a significant relationship between sand and silt and between clay and silt. The Correlation is significant at the 0.01 level. Between sand and silt a correlation value of $r=$ 0.772 implies that $59.5984 \% \approx 60 \%$ reduction in 
sand will lead to an increase in silt. This is logical since sand particles over time of weathering and degradation may form a proportion of silt insitu or transported and deposited in other areas. Between silt and clay a correlation value of $\mathrm{r}=-0.578$ exist implying that $33.4084 \%$ of silt have contributed to the status of clay in the area, and as silt increases, clay reduce in an inverse relationship.

\section{Linear Multiple Regression Analysis}

A linear multiple regression analysis was used to check the contribution or influence of each independent variable on the dependent variable (Table 5). In Saye, Aggregate stability, bulk density, \%clay, \%silt show $84.8 \%$ influence adjusted to $81.0 \%$ influence. Clay and silt contribute significantly to the value of clay ratio. At $95 \%$ confidence we can infer that a decrease in 0.395 of \%clay contributes to the current value of clay ratio and an increase in 0.144 of $\%$ silt leads the value of clay ratio both respectively. The regression equation is as given below:
Clay ratio $=10.893+-0.395$ clay + silt +0.144 silt .648 bulkdensity +0.04 laggregate stability

At Kubanni bulk density, \%clay, and \%sand show $82.6 \%$ influence adjusted to $79.5 \%$ influence which significant since $\mathrm{p}<0.05$ at 0.05 level of significant. The contributions of clay and bulk density are negatively significant to the present value of clay ratio. The regression equation is as given below:

\section{Clay ratio $=47.089-1.820$ clay-.056sand 9.409bulk density.}

At Guga aggregate stabilty, \%silt, bulk density, $\%$ clay show $62 \%$ influence adjusted to $52.5 \%$ influence which significant since $\mathrm{p}<0.05$ at 0.05 level of significant. Clay contributed significantly to the clay ratio value obtained. A decrease in 0.997 clay leads to the current value of clay ratio. The regression equation is as given below:

Clay ratio $=38.021-0.997$ clay +0.090 silt -5.987 bulk density-1.388aggregate stability.

Table 4: Correlation analysis

\begin{tabular}{|c|c|c|c|c|c|c|c|}
\hline Gully site & Variables & $\%$ Clay & $\%$ Silt & $\%$ Sand & Clay Ratio & & \\
\hline \multirow[t]{4}{*}{ GUGA } & \%Clay & 1 & $-.705^{* *}$ & .157 & $-.773^{* *}$ & & \\
\hline & $\%$ Silt & $-.705^{* *}$ & 1 & $-.811^{* *}$ & $.618^{* *}$ & & \\
\hline & $\%$ Sand & .157 & $-.811^{* *}$ & 1 & -.223 & & \\
\hline & Clay Ratio & $-.773^{* *}$ & $.618^{* *}$ & -.223 & 1 & & \\
\hline \multirow[t]{4}{*}{ KUBANNI } & $\%$ Clay & 1 & $-.569^{* *}$ & .151 & $-.881^{* *}$ & & \\
\hline & $\%$ Silt & $-.569^{* *}$ & 1 & $-.899^{* *}$ & $.512^{*}$ & & \\
\hline & $\%$ Sand & .151 & $-.899^{* *}$ & 1 & -.146 & & \\
\hline & Clay Ratio & $-.881^{* *}$ & $.512^{*}$ & -.146 & 1 & & \\
\hline \multirow[t]{5}{*}{ SAYE } & $\%$ Clay & 1 & -.261 & $-.517^{*}$ & $-.863^{* *}$ & & \\
\hline & $\%$ Silt & -.261 & 1 & $-.692^{* *}$ & $.534^{*}$ & & \\
\hline & $\%$ Sand & $-.517^{*}$ & $-.692^{* *}$ & 1 & .172 & & \\
\hline & Clay Ratio & $-.863^{* *}$ & $.534^{*}$ & .172 & 1 & & \\
\hline & Bulk Density & .068 & .280 & -.299 & .014 & & \\
\hline \multirow[t]{8}{*}{ YASHI } & & $\%$ Clay & $\%$ Silt & $\%$ Sand & Clay Ratio & Bulk Density & Aggregate Stabilty \\
\hline & $\%$ Clay & 1 & .415 & $-.926^{* *}$ & $-.867^{* *}$ & -.183 & -.404 \\
\hline & $\%$ Silt & .415 & 1 & $-.728^{* *}$ & -.258 & $-.504^{*}$ & -.381 \\
\hline & $\%$ Sand & $-.926^{* *}$ & $-.728^{* *}$ & 1 & $.761^{* *}$ & .343 & $.459^{*}$ \\
\hline & Clay Ratio & $-.867^{* *}$ & -.258 & $.761^{* *}$ & 1 & -.093 & $.517^{*}$ \\
\hline & Bulk Density & -.183 & $-.504^{*}$ & .343 & -.093 & 1 & .020 \\
\hline & Aggregate & -.404 & -.381 & $.459^{*}$ & $.517^{*}$ & .020 & 1 \\
\hline & Stabilty & & & & & & \\
\hline \multirow[t]{7}{*}{ COMBINED } & & $\%$ Clay & $\%$ Silt & $\%$ Sand & Clay Ratio & & Aggregate Stability \\
\hline & $\%$ Clay & 1 & $-.578^{* *}$ & -.071 & $-.790^{* *}$ & & -.208 \\
\hline & $\%$ Silt & $-.578^{* *}$ & 1 & $-.772^{* *}$ & $.729^{* *}$ & & .155 \\
\hline & $\%$ Sand & -.071 & $-.772^{* *}$ & 1 & $-.277^{*}$ & & -.027 \\
\hline & Clay Ratio & $-.790^{* *}$ & $.729^{* *}$ & $-.277^{*}$ & 1 & & $.215^{*}$ \\
\hline & Bulk Density & -.042 & .140 & -.139 & -.024 & & .022 \\
\hline & $\begin{array}{l}\text { Aggregate } \\
\text { Stability }\end{array}$ & -.208 & .155 & -.027 & $.215^{*}$ & & 1 \\
\hline
\end{tabular}


Table 5: Coefficients of Variables Influencing Clay Ratio at Saye Gully Site

\begin{tabular}{|c|c|c|c|c|c|c|}
\hline \multirow{3}{*}{$\begin{array}{l}\text { GULLY } \\
\text { SITE }\end{array}$} & \multicolumn{4}{|l|}{ Coefficients $^{\mathrm{a}}$} & \multirow{3}{*}{$\mathrm{t}$} & \multirow{3}{*}{ Sig. } \\
\hline & \multirow[t]{2}{*}{ Model } & \multicolumn{2}{|c|}{ Unstandardized Coefficients } & Standardized & & \\
\hline & & $B$ & Std Frror & Beta & & \\
\hline \multirow{7}{*}{ SAYE } & (Constant) & 10.893 & 3.768 & & 2.891 & .011 \\
\hline & $\%$ CLAY & -.395 & .056 & -.778 & -7.081 & .000 \\
\hline & $\%$ SILT & .144 & .048 & .336 & 3.018 & .008 \\
\hline & BULK & -.648 & 2.533 & -.027 & -.256 & .801 \\
\hline & DENSITY & & & & & \\
\hline & AGGREGATE & .041 & .283 & .016 & .146 & .886 \\
\hline & STABILTY & & & & & \\
\hline \multirow[t]{5}{*}{ KUBANNI } & (Constant) & 47.098 & 9.551 & & 4.931 & .000 \\
\hline & $\%$ CLAY & -1.820 & .210 & -.891 & -8.684 & .000 \\
\hline & $\%$ SAND & -.056 & .113 & -.052 & -.497 & .626 \\
\hline & BULK & -9.409 & 4.316 & -.225 & -2.180 & .044 \\
\hline & DENSITY & & & & & \\
\hline \multirow[t]{7}{*}{ GUGA } & (Constant) & 38.021 & 27.412 & & 1.387 & .184 \\
\hline & $\%$ CLAY & -.997 & .321 & -.735 & -3.100 & .007 \\
\hline & $\%$ SILT & .090 & .188 & .112 & .481 & .637 \\
\hline & BULK & -5.987 & 12.757 & -.084 & -.469 & .645 \\
\hline & DENSITY & & & & & \\
\hline & AGGREGATE & -1.388 & 2.069 & -.122 & -.671 & .512 \\
\hline & STABILTY & & & & & \\
\hline
\end{tabular}

\section{Conclusions and Recommendation}

Following the findings of this research, the conclusion is drawn that there is a significant variation of clay, silt, sand, clay ratio and aggregate stability with gully sites at 0.05 levels of significance. That means each gully site deserves to be given specific and special attention. Also that there is There is a significant negative relationship between CLAY RATIO and clay (i.e $r=-0.773^{* *}$ ) implying that the higher the clay, the lower the clay ratio thus the more resistance to erosion and a significant positive relationship between Clay Ratio and \%Silt (i.e $\mathrm{r}=0+.618^{* * *}$ ) also implying that the higher the silt content, the higher the value of clay ratio and thus the less resistance to erosion. The same kind of relationship between CLAY RATIO and clay, and between Clay Ratio and \%Silt also exist in all gully sites. This is similar to the works of Igwe $(2003 ; 2005$; and 2011) in some parts of the country. The value of clay ratio obtained by Alhassan et al., 2012 under different agro forestry practices in Kwande Local Government Area and Mallo and Mgbanyi (2013?) (on miniature badlands at Gada Biyu, Abuja, Federal Capital Territory, Nigeria were parts similar attempts by scholars to compare the erodibility of different land uses and landscapes.The regression model also reveals the contribution of each parameter to the state of resistance to erosion

\section{References}

Abrishamkesh, S., Gorji, M. and Asadi, H. (2011). Long-term effects of land use on soil aggregate stabilty. International Agrophysics, 25: 103-108.

Alekseeva, T.V., Sokolowska, Z., Hajnos, M., Alekseev, A.O. and Kalinin, P.I. (2009). Water stability of aggregates in subtropical and tropical soils (Georgia and China) and its relationships with the mineralogy and chemical properties. Eurasian Soil Science, 42: 415-425.

Amezketa, E. (1999). Soil aggregate stability: a review. Journal of Sustainable Agriculture, 14: 83-151.

Bello, A.L. (1973). The Morphology of an Erosional scarp south of Ahmadu Bello University, Zaria. Unpublished B.A thesis, Department of Geography, A.B.U Zaria.

Bouyoucos, G.J. (1935). The clay ratio as a criterion of susceptibility of soils to erosion. Journal of American Society of Agronomy, 27: 738-751.

Cerda, A. (1998). Soil aggregate stability under different Mediterranean vegetation types. Catena, 73-86. http://dx.doi.org/10.5772/52473

Igwe, C.A. (2005). Erodibility in relation to water-dispersible clay for some soils of 
eastern Nigeria. Land Degradation and Development, 16: 87-96.

Igwe, C.A. (2003). Erodibility of soils of the upper rainforest zone, southeastern Nigeria. Land Degradation and Development, 14: 323-334.

Igwe, C.A. (2011). Tropical soils, physical properties. In J Glinski, J Horabik, J Lipiec (Eds.), Encyclopedia of Agrophysics (1st ed.), Springer; 934-937.

Imeson, A.C. (1984). An eco-geomorphological approach to the soil degradation and erosion problem. En Fantechi, R., Margaris, N.S. (Eds.) Desertification in Europe, pp. 110-125

Imeson, A.C. and Vis, M. (1984). Assessing soil aggregate stability by water-drop impact and ultrasonic dispersion. Geoderma, 34: 185-200.

Jaiyeoba, 1.A (1995). Changes in Soil Properties relation to Different Landuses in Part of the Nigerian Semi-arid Savanna. Soil Use and Management, 11: 84-89

Juo, A.S.R and Lal, R. (1977). The Effect of Fallow and Continuous Cultivation on Chemical and Physical Properties of an Alfisol in Western Nigeria. Plant Soils 47, 567-584

Keli, Z., Shuangcai, L. and Wenying, P. (2002). Erodibility of Agricultural Soils in the Loess Plateau of China. Soil and Water.

Kowal, J. and Omolokun, A.O. (1971). The Hydrology of a small catchment basin at Samaru, Nigeria. Nigeria Agricultural Journal, 7(1): 27-40.

Kowal, J.M. and Knabe, D.T (1972) An Agroclimatologi cal Atlas of the Northern Stales of Nigeria. A.B.U Press, Zaria, Nigeria.

Kowal, J.M. and Kassam, A.H. (1976). Energy load and instantaneous intensity of rainstorms at Samaru, northern Nigeria. Trop.Agric., 53(3):185-197.

Leow, K.S. and Smith, B.J. (1981). "Soil p" and Textural Variation in the Eluviated 'A' Horizon on Basement Slopes under a Savanna Climate" Geomorph. N. F Vol 25, No 1, pp73-98.

Mallo, I .I. Y. and Ochai, B. C. (2009). Assessment of the effects urbanization on deforestation in Bwari area council, Abuja Federal Capital Territory, Nigeria.
The Abuja Journal of Geography and Development, 3(1): 1-19.

Mallo, I.I.Y. (1987). Slope Morphology, Soil Property Variation and Rates of Soil wash in an area Southern Zaria. Unpublished M.Sc thesis, Dept of Geography, ABU Zaria.

Mallo, I.I.Y and Mgbanyi, L.L.O. (2013). Assessment of Soil Wash and Soil Erodibility Indices on Miniature Badlands at Gada Biyu, Abuja, Federal Capital Territory, Nigeria. Ethiopian Journal of Environmental Studies and Management Vol. 6 No.2

Ojiah, O.R. (1998). Effect of soil physical properties on Gully Erosion in three basins Near the Zaria region. Unpublished B.Sc Thesis, Department of Geography, A.B.U Zaria. Pp 1-47.

Ojo, F.O. (2000). Soil physical characteristics and Gully Erosion. Unpublished B.Sc. Thesis, Department of Geography, A.B.U Zaria.

Ologe K.O. (1986). "Soil Erosion Characteristics, Processes and Extent in the Nigerian Savanna". In Sagua V.0 (et al) Ecological Disasters in Nigeria: Soil Erosion. Fed. Mm. of Sci. and Techno, Lagos. pp $26-49$.

Portugal, A. F., Juncksh, I., Schaefer, C.E.R.G. and Neves, J.C.D.L. (2010). Aggregate stability in an ultisol under different uses, compared with forest. Estabilidade de agregados em argissolo sob diferentes usos comparado com mata. Retrieved from http://www.ceres.ufv.br

Sheyin, T. (1989). Gully intensity in relation to soil characteristics in the upper Kubanni, river basin. Unpublished B.A Thesis, Department of Geography, A.B.U Zaria.

Singh, M.J. and Khera, K.L. (2008). Soil erodibility indices under different land uses in lower Shiwaliks. Soil and Water, 49(208), 113-119.

Stocking, M.A. and Elwell, H.A. (1976). Rainfall Erosivity over Rhodesia IN: I.B.G.N.S Vol 1, no 1, pp 23 1-245.

Yakubu, S. (2004). Assessment of Soil Changes under Different Landuses in Zaria Area, Northern Nigeria. Unpublished M.Sc thesis, Dept of Geography, ABU, Zaria. 